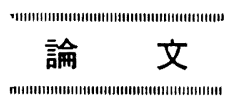

\title{
焼入中の鋼の内部応力と残留応力の計算*
}

\author{
利岡靖継**・深川宗光***・杂保賀喜規***

\section{Computation of Internal Stress for Steel Bar during and after Quenching}

\author{
Yasutsugu Toshioka, Munemitsu Fukagawa, and Yoshinori SAIGa
}

Synopsis:

To draw benefits from fast quenching to strengthen and toughen as well as to increase the fatigue strength by taking advantage of residual stress, the stresses given rise to in steels during and after quenching were computed.

The quenching stress, which is due to thermal strain and transformation strain, was presented as a function of changes of temperature distribution, while the method of quenching and the sizes of steel articles were conceived as the factors that determined the temperature distribution. For the steel articles state during quenching, elastic parts and plastic parts were discriminated on the basis of the maximum shear stress theory, and the transient stress distributions were obtained by integrating the stress from the quenching temperature down to an instantanius temperature.

The computations revealed:

1) The superficial tensile stress becomes maximum during quenching just before the transformation at the center is completed, whereas, in cases of imperfect quench, the central tensile stress becomes maximum when the steel as a whole is cooled to the room temperature.

2) For the case of perfect quench, the superficial tensile stress is the greater the severer the quenching, though it decreases beyond a certain limit of quenching speed even becoming comperession.

3) For imperfect quench, the stress distribution, though much depends on the quenched structure and the severity of quenching, is generally such that the superficial stress is compressive and often a sharp peak of tensile stress exists at just below the surface.

A few practical applications have been presented and discussed.

(Received Feb. 13, 1971)

\section{1. 緒言}

鋼在焼入れうときに生ずる内部応力は焼制れ，䈯割れ などの原因として有害であら反面, 残留応力を有効に利 用することに上つて疲労強さを向上させるなどの効果も 持つている. 最近の機械装置の大型化, 高能力化に伴つ て，合金鋼の中でも上り強鞂性にすへれた鋼材が使われ ることが多くなつてきていう.大型鉎鋼品の焼入れは油 焼入れによることが多いが，著者らもすでに報告したよ うに に低下古る。質星效果については外国においても研究が 進められ2)，この問題はほぼ明らかになつたと思われる。

機械模造用鋼の強鞂性をさらに向上させるには，合金 組成の操作，あるいはより急速な焼入法の採用によつて 烍入れを完全に近ゔけること，抢よび残留応力虹利用与 ることなどの方法が考えられる。焼入れを完全に近づけ
るには油器入れよりも水筧入れ，あるいは空気・水のス プレー筧入れふ効紧的であることは言うにおよばない ふ，焼颔れの発生が眯念され大径の機械構造用合金鋼に 採用されることは現状ではまれである. 残留応力を有効 汇利用することは高周波焼入れをした鋼材では行なわれ ているが，調犋鋼については积極的な意味ではほとんご 行なわれていない，焼割れや残留応力は鋼を焼入れたと きに生ずる内部応力の結果であるが，焼入れ中の応力は 实测不可能であること, 残留応力測定のデータ蓄積は行 なわれてはいるものの, 大型鉎鋼品の場合測定に経済的

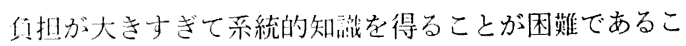
しなどが焼入れ忍力の积極的利用をさまたげている理由

* 炤和45年10月本会篮演大会にて発表 昭和46年 2 月 13 日受付

** 石川鼠播磨啠工丵

*** 石川品播瀿画工業 工博 
と思われる。

ここで，著者らは筧入れ中に発生する内部応力を計算 によつて求め, 最初の段階として急激な焼入れの採用に よる鋼の強靶化を試みた・計算によつて求めた結果は他 の研究者による残留応力の実測とくらべてよい一致をみ るこレができたので，計算方法の概要と計算結果をここ に報告する.

\section{2. 焼入応力発生の概念と計算の前提}

鋼の焼入応力を計算によつて求める試みは1927年 $E d$. MAURER ${ }^{3}$ が最初と言われ，わが国でも広根德太郎4)，下 田秀夫5らによつてすでに行なわれている。仮定の技き 方や計算手順は異なつているょしても, 下田の方法上著 者らの方法は本質的に同じ考え方に立つていると思われ る.ただ, 下田の方法では燒入れ中の弾塑性の分雒を適 当な温度を仮定するこ上によつて行なつており, 塑性状 態での応力が取り入れられていない，著者らは最大韵断 応力説を用いることによりこの二つを解決した．以下: 述べる記号の意味はとくに注記しない限り次に示与.

鋼の焼入れ応力は焼入れ中の温度变化に伴つて発生す る熱歪と変態歪の不均一に上るものである・したがつて， 汾却沪要する時間上は直接の関係はなく, 温度分布の变 化量だけに依存すると考えてよい。いま，鋼の丸棒を焼 入れてマルテンサイト一相に変態する場合を考える. 焼 入れ途中の任意の時点での温度分布が: Fig. 1 の実線の ようであつたとし, 微少時間後に点線のような温度分布

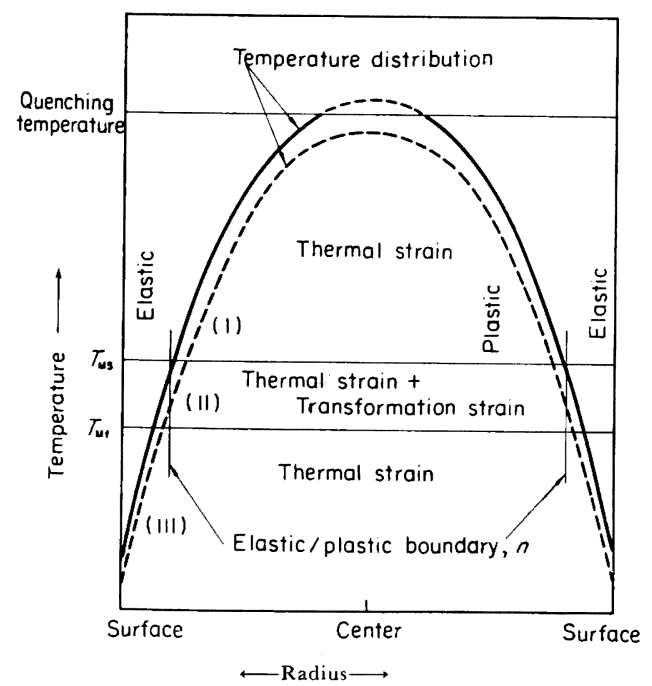

Fig. "1. Schematic diagram for temperature distribution and strain induced by change of temperature distribution.
記 号
$R:$ 丸棒の半径
$(\mathrm{mm})$
$r$ : 半径方向位置
( $\mathrm{mm})$
$n$ ：典次元化した弾塑性垷界
$B$ : 無次元化した弾性状態部分の外周
$E:$ : グ率
$\left(\mathrm{kg} / \mathrm{mm}^{2}\right)$
$K^{\prime}:$ 体䅡弾性率
$\left(\mathrm{kg} / \mathrm{mm}^{2}\right.$ )
$m$ : ホアソン数
$T:$ 温度
$T_{0}:$ 中心温度
$T_{r}:$ 位置 $r$ の温度
$T_{s}:$ 変態閒始温度
$T_{f}:$ 変態終了温度
$\varepsilon: 7$.
$(\mathrm{mm} / \mathrm{mm})$
$J \varepsilon:$ 全変態歪
( $\mathrm{mm} / \mathrm{mm}$ )
：：変態中の剪断弹性限応力
$\left(\mathrm{kg} / \mathrm{mm}^{2}\right.$ )
\lrcorner : : 変態組織の罗断弹性限灾力
$\left(\mathrm{kg} / \mathrm{mm}^{2}\right)$
$A$ : 断面の温度分在を示方倸数, 泠却方法上直径から 定をる
$J$ : 中心の筧入れ組織に占めるマルテンサイトの比
$K:$ 断面の焼入れ組織を示与倸数
$\sigma_{r}, \sigma_{t}, \sigma_{z}:$ それぞれ半径, 接線および軸方向応力

$\left(\mathrm{kg} / \mathrm{mm}^{2}\right)$

添字 $M, B: T_{M f}$ のよう:こMまたは $B$ の添字が加わつ ているときはマルテンサイトまたはベイナイト の值を示す.

接頭字 $d: d \sigma_{r}$ などのように頭に $d$ がついているとき は微分量を小古。

に変化したとする.この温度変化に対して, 温度変化に 相当する熱収縮が全体に生じ, 变態温度域 $T_{M s} \sim T_{M f}$ 間では変態の進行による膨張が生ずる，膨張が生ずるの は $T_{M s} \sim T_{M f}$ 閒だけであるので, この時発生する内部 応力は温度が $T_{M s}$ 以上の位置 (I)で引つ張り, $T_{M S} \sim$ $T_{M f}$ 間の位置(II)で压縮そして $T_{M f}$ 以下(II)では引 つ張りとなるであるう.オーステナイトの剪断弾性限応 力は小さいが, $T_{M s} \sim T_{M f}$ 間では変態が進行するため 鋼の剪断弾性限忍力はある值だけ增加する. 以下に述べ るように焼入れに伴う現象をモデル化して，この歪発生 をもとに弾性計算を行なうと, 变態開始位置に発生する 剪断力は鋼の剪断弹性限応力の増加をはるかに越えてお り, 变態終了位置では越えていないことが容易に知ら れ，弾性計算は成り立たないことがわかる。したがって， $T_{M s} \sim T_{M f}$ 間に存在する弾塑性境界を求め，しかるの ち微少温度变化に対与る歪発生をもとに弾塑性計算を行 なわ水ばならない。このような考虑を払いながら，焼入 

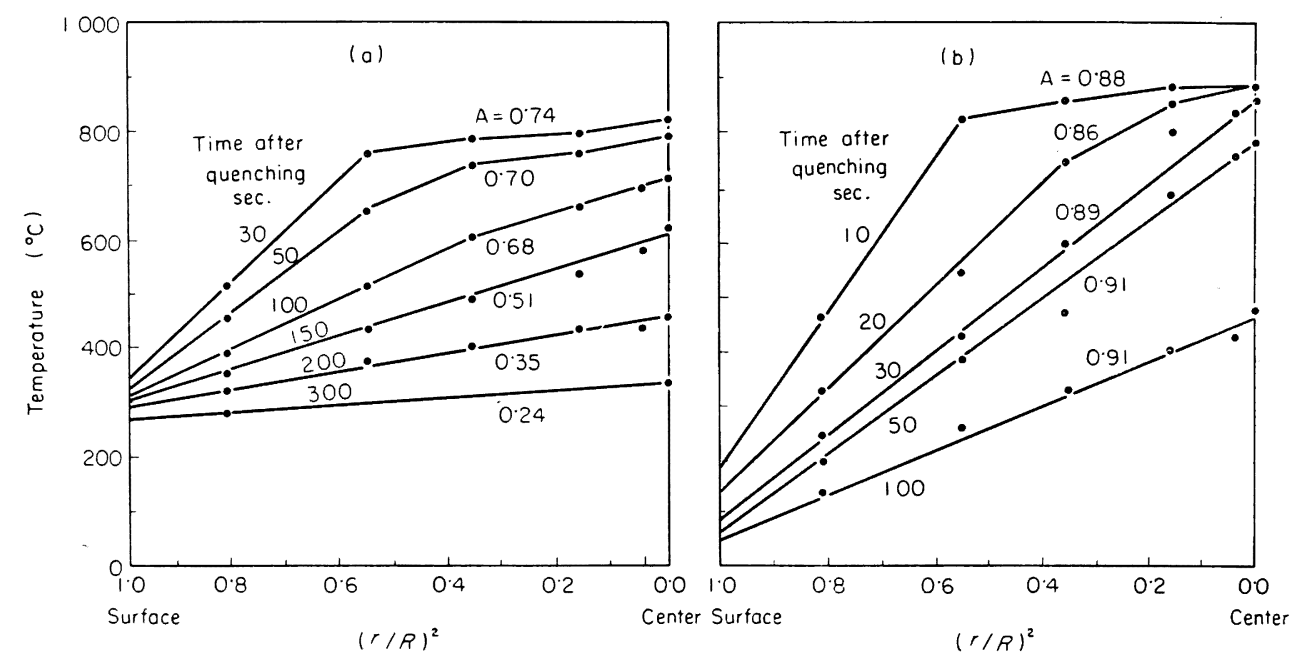

Fig. 2. Temperature distribution in the cross section of a steel quenched (a) in oil from $850^{\circ} \mathrm{C}$. (b) in water from $900^{\circ} \mathrm{C}$.

れ温度ふら任意の温度まで，発生する応力を積分して行 けば焼入中の過渡的内部応力分布が求まるはずである.

この計算を行交うに当たつて, 焼入中の温度分布, 変 態の進行, 変態汇上る弾性限強さその他の物性値を数式 化することが必要である。計算に先立つてこれらの数式 化について述べる.

\section{$2 \cdot 1$ 温度分布}

焼入中の過渡的温度分布に対して辟密な理論式を適用 するこには，後の計算に無理があるし，また熱伝濂率な どの物性值に温度供存性があつて, 実際上正確な答を得 ることも困難である。それゆ元，実測をもとに作図的に 温度分布を簡単な形に近似した．直径 $100 \mathrm{~mm}$ の鋼を静 止した水と油に焼入れたときの温度分布を Fig. 2(a), (b)に示す. 実験の方法を簡単に述べると, 試料はS 45 $\mathrm{C}$ の直径 $100 \mathrm{~mm}$ 長さ $300 \mathrm{~mm}$ の鋼を用い, 端面より $150 \mathrm{~mm}$ の深之まで断面位圆 $r / R=0,0 \cdot 2,0 \cdot 4,0 \cdot 6$, 0.74 および 0.9 江直径 $5 \mathrm{~mm}$ のキリ穴をあけクロメル ・アルメル熱電対を穴底に溶接して焼入中の温度を測定 した.

Fig. 2 の横軸は $(r / R)^{2}$ として表わしてあるが, 温度 分布は次の形で近似できることを示している.

$$
T_{r}=T_{0}+\beta \cdot(r / R)^{2}
$$

ここで $\beta$ は温度勾配を示す係数， $T_{0}$ は中心温度である. (1)式をさらに次のように打きかえる.

$$
T_{r}=\left\{1-A \cdot(r / R)^{2}\right\} T_{0} \cdots
$$

Fig. 2 に(2)式で近似したときの倸数 $A$ の值を記入し ておいたが水焼入れの場合は $A=0.9$ とおくことができ
る・油焼入れは $A$ の値が時間の経過と共に小さくなつて いる.

熱伝達率，熱伝導度などが温度によらず一定であるな ら温度勾配を六寸係数 $A$ は $k / h R$ （ただし， $k$ : 熱伝導 率, $h$ : 熱伝涬率, $R$ : 丸棒の半径), だけに支配され 温度によらないが6), 油焼入れでは熱伝達率の温度依存 性が大きいため，Aの值は低下すると考光られる。油焼 入れの温度分布は交献 7) からも求められる.この計算 では $(2)$ 式を用い, 実際問題への適応においては $A$ の平 均值で行なつた. 直径 $100 \mathrm{~mm}$ の鋼は水焼入れで $A=$ $0 \cdot 9$, 油焼入れで 0.4 前後である.

\section{$2 \cdot 2$ 変態の進行}

SCM4 について実測したマルテンサイト変態の進行

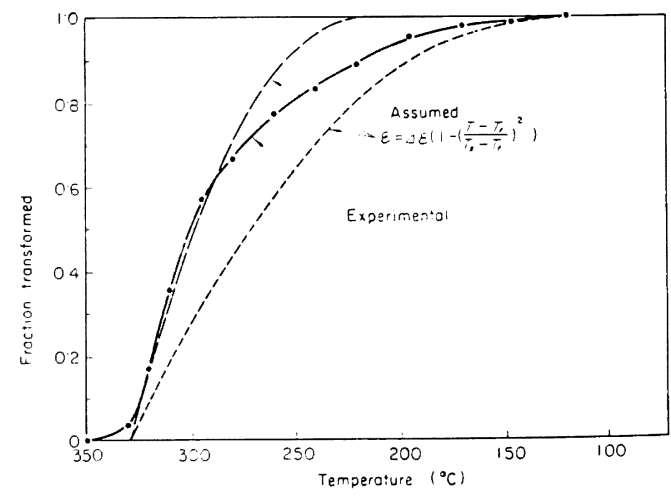

Fig. 3. Progress of martensite transformation and approximated equation used. 


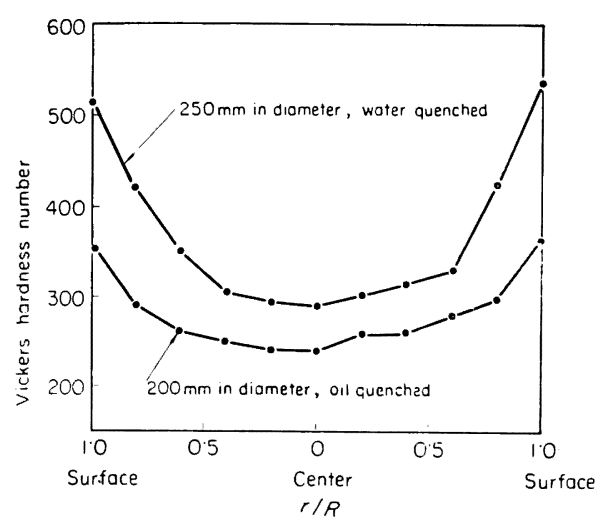

Fig. 4. Hardness distributions after quenching of medium carbon $\mathrm{Cr}$-Mo steels.

を Fig. 3 に示す. 变態の進行は指数的な形となるよう であるが，後の演算の都合もあつて（3)式のように二乘 で近似した.この近似では計算上の变態終了温度 $T_{f}$ を 実際の $T_{s}$ と $T_{f}$ のほぼ中間におくことが必要である。

$$
\varepsilon=\Delta \varepsilon\left\{1-\left(\frac{T-T_{f}}{T_{s}-T_{f}}\right)^{2}\right\}
$$

\section{3 蠎入組䋨}

完全焼入の場合は焼入組織がマルテンサイト一相であ るので問題はないが，マルテンサイトとベイナイトの二 相に不完全焼入される場合は, 断面の組織分布を知る必 要がある.SCM4について実測した断面の焼入硬さ分布 を Fig. 4 に示すが，この結果からマルテンサイトおよ びベイナイトの量比（ $M$ および $B)$ を試片の相対位置 $(r / R)$ に対して $(4)$ 式のように近似した。

$$
\begin{aligned}
& \text { マルテンサイト : } \left.M=J+K \cdot(r / R)^{2}\right) \\
& \text { ベイナイト: } B=1-J-K \cdot(r / R)^{2} \\
& M+B=1
\end{aligned}
$$

\section{4 焼入中の銅の曽断弾性強さ}

オーステナイトでは弾性限強さは小さいのでゼロと才う く. 変態開始後は変態量に比例して弾性限強さは高くな ると仮定した。すなわち(5)式が成り立つとした。

$$
\tau=\Delta \tau\left\{1-\left(\begin{array}{c}
T-T_{f} \\
T_{s}-T_{f}
\end{array}\right)^{2}\right\}
$$

\section{5 降伏条件}

多軸応力場における降伏条件として最大剪断応力説 を用いた。亦わち，接線方向応力と半径方向応力の差 の $1 / 2$ が鋼の䇂断弾性限強さに達したとき, 鋼は降伏し て塑性となるとおいた。

計算上の大きな前提は以上の通りであるが，線膨張係 数, ヤング率, ホアソン数の温度依存性は無視した。

\section{3. 弾塑性の分離}

前節で述べた前提から中心温度の微少変化に対して各 位置の温度変化が与えられ，発生する歪がわかる。すて に述ベたようにオーステナイトは塑性であり，変態の進 行する先端部に発生するせえ応力が椫性限を越えている と推定されるので, Fig. 1に示すように変態域の中に弾 塑性境界 $n$ を仮定し，次に述べる方法で $n$ を求めた。 す なわち $n$ より内部は塑性であり, $n$ の外部は弾性であ る. nの内部に塑性歪，nの外部に弾性歪が発生したと き, 弾性側の $n$ に貝断力を発生する. $n$ は弾塑性境界で あるから， $n$ に発生する剪断力は䤱の剪断弾性強さの変 化量に等しいはずである. 中心温度が $d T_{0}$ 变化するこ とによつて塑性側に歪 $\varepsilon_{p}$ が発生し, 静水圧 $d P$ と位置 $n$ に変位 $v$ とが生じたと少ると，体積と压力の関係が (6)式のようになるので，(6)式からvは（7)式で与え られる。

$$
\pi(n+v)^{2}\left(1+\varepsilon_{z}\right)=\left(\bar{n}_{i}{ }^{2}-\varepsilon_{p}\right)\left(1+\frac{d P}{K^{\prime}}\right)
$$

(6)式より

$$
v=\frac{1}{2 n}\left(\frac{\varepsilon_{p}}{\pi}+n^{2} \frac{d P}{K^{\prime}}-n^{2} \varepsilon_{z}\right)
$$

ここで $\varepsilon_{z}:$ 軕方向の変位

$$
\begin{aligned}
\varepsilon_{z} & =\frac{2}{1-n^{2}} \int_{v}^{1} d \varepsilon \cdot(r / R) \cdot d(r / R)-\frac{n^{2}}{1-n^{2}} \cdot \frac{d P}{E} \\
\varepsilon_{p} & =6 \pi \int_{0}^{n} d \varepsilon \cdot(r / R) \cdot d(r / R)
\end{aligned}
$$

弾性体側より計算すればvは（8)式で与えられる.

$$
\begin{aligned}
& v=\frac{2(m+1)}{m} \cdot \frac{n^{2}}{1-n^{2}} \int_{v}^{1} d \varepsilon \cdot(r / R) \cdot d(r / R) \\
& -\frac{(m+1) n}{m E\left(1-n^{2}\right)}-\left(\frac{m-2}{m} n^{2}+1\right) d P \\
& -\frac{m}{m}\left(\frac{2}{1-n^{2}} \int_{v}^{1} d z \cdot(r / R) \cdot d(r / R)-\frac{n^{2}}{1-n^{2}} d P\right.
\end{aligned}
$$

(7)式と (8) 式は等しいはずであるので $d P$ は (9) 式のように与えられる。

$$
d P=\frac{6 n^{2} \int_{v}^{1} d \varepsilon \cdot(r / R) \cdot d(r / R)-\varepsilon_{p}\left(1-n^{2}\right)}{\frac{n^{2}\left(1-n^{2}\right)}{K^{\prime}}+{ }_{m}^{2}\left\{\begin{array}{c}
(3 m+2)(m-2) \\
m
\end{array} n^{2}+2(m+1)\right\}}
$$

以上より, 中心温度の変化 $d T_{0}$ 江対して位雷 $n$ に発 生する剪断力は (10)式で与えられる。

$$
\begin{aligned}
& \frac{1}{2} d \tau=d \sigma_{t}-d \sigma_{r}=\frac{m E}{m-1} . \\
& \left.\left(\frac{2}{1-n^{2}} \int_{v}^{1} d \varepsilon \cdot(r / R) d(r / R)-d \varepsilon\right)-\frac{2}{1-n^{2}}\right) d P
\end{aligned}
$$


(10)

中心温度の変化 $d T_{0}$ に対して位置 $n$ に打省素材の 弾性限の增加 $d \tau$ は (5) 式に (2) 式，(4) 式を代入し て，これを微分することにより与えられる。たとえばマ ルテンサイト变態域では(11)式のとおりである.

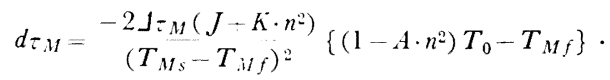

$$
\begin{aligned}
& \left(1-A \cdot n^{2}\right) d T_{0}
\end{aligned}
$$

弾塑性境界に打いては発生する愬断力 $d \tau\left[=\frac{1}{2}\left(d \sigma_{t}-\right.\right.$ $\left.\left.d \sigma_{r}\right)\right]$ 之素材の弾性限の増加之は釣合つているから(10) 式上(11)式を满足するnの值が微分的な弾塑性位置であ る.微分的なという意味は素材の弾性強さがゼロから始 まる場合は弹塑性の分攡が行なわれても，ある值から始 まる場合, 寸なわら，ナでにベイナイト変態が行交われ て，ある弾性強さを持つている場合，マルテンサイト変 態中に生ずる剪断力の顸分们が菜材強さの微分值を越元 ていても絶刘值として越えていないことも市り得るから である. ゆ元に, 最初の変態組織に対しては上の解は弾 塑性を分嗺するが第二相, 寸なわち, ベイナイト変態先 行後のマルテンサイト変態ではさらに発生する剪断力の 积分を行ない，素材の弾性限を越えるか否かに上つて弾 塑性の分離を行なわ权ばならない。

Table 1 のデータを用いて求めた燒入中の弾塑性の状 態の例を Fig. 5 に示す. Fig. 5 は谠入組織が $M=0 \cdot 1$ $+0.4(r / R)^{2}, A=0.5$ の場合で縦帆に $(r / R)^{2}$, 横帆に 中心温度をとり罁の状態を示してある.中心温度は焼入 温度以上では仮想の温度であるが，中心が $800^{\circ} \mathrm{C}$ 立で 低下したとき表面は $400 \mathrm{C}$ となつて扒り, $(r / R)^{2}=0 \cdot 87$ の位置がベイナイト変態終了温度の $450 \mathrm{C}, \quad(r / R)^{2}=$ 0.75 がベイナイト変態阙始温度の $500^{\circ} \mathrm{C}$ である. $T_{B s}$ の線は中心温度に対してベイナイト变態開始温度の位置 を示し， $T_{B !}, T_{M S}, T_{M f}$ も同惟である. ベイナイト， マルテンサイトの变態温度域の实線が求めた微分的弾塑

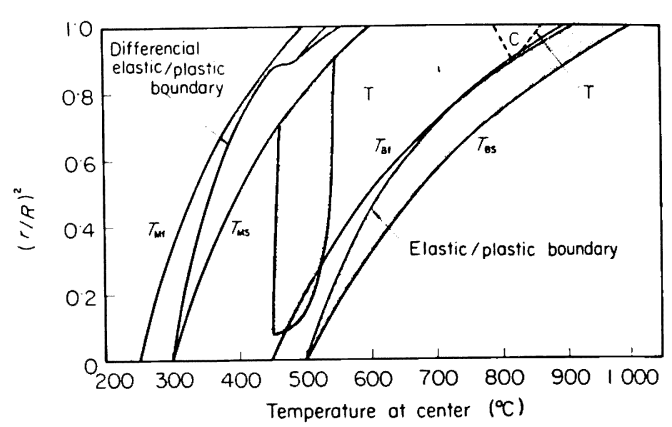

Fig. 5. Differential elastic and plastic boundary, and distributions of plastic regions. $A=0.5, J=0 \cdot 1$, and $K=0 \cdot 4$

性境界であつて，オーステナイトの位置と陰影を注どこ したところが塑性状態である. マルテンサイトとベイナ イトの間に存在する塑性はベイナイト変態による膨張に より生じた引張塑性である. 図中の $T$ または $C$ は剪断力 の状態が引張または圧縮であることを示している・鋼を 呰入れたときの弾塑性の状態は完全焼入では比較的単純 であるが，不完全焼入ではこのように複雑である.

\section{4. 焼入応力の計算}

以上で弾塑性の区分ができたので応力の計算が可能で ある、焼入れてから表面が変態を開始するまでは全体が オーステナイトであるので㦄力分布はゼロである．表面 が変態を開始してのち中心温度をわずかずつ变化させ， 各位置に発生する応力を任意の中心温度まで積分する. すなわち，次のような式を基本上して演算手順を構成す る.

\section{$4 \cdot 1$ 変態を伴う塑性域に生ずる応力}

最大剪断応力説上り

$$
\begin{aligned}
& d \sigma_{t}-d \sigma_{r}=2 d \tau \\
& d \sigma_{z}=\frac{1}{2}\left(d \sigma_{r}+d \sigma_{t}\right)
\end{aligned}
$$

Table 1. Physical data of steel for computation.

Strain due to bainitic transformation $\left(J \varepsilon_{B}\right)$

Strain due to martensitic transformation $\left(J \varepsilon_{M}\right)$

Starting point of bainitic transformation $\left(T_{B S}\right)$

Finishing point of bainitic transformation $\left(T_{\mathrm{Bf}}\right)$

Starting point of martensitic transformation ( $T_{\mathrm{MS}}$ )

Finishing point of martensitic transformation $\left(T_{\mathrm{Mf}}\right)$

Linean expansion coefficient $(\alpha)$

Elastic limit in shear of bainite $\left(J \tau_{\mathrm{B}}\right)$

Elastic limit in shear of martensite $\left(J \tau_{M}\right)$

Quenching temperature (Q. T.)
$40 \cdot 10^{-4} \mathrm{~mm} / \mathrm{mm}$

$50 \cdot 10^{-4} \mathrm{~mm} / \mathrm{mm}$

$500^{\circ} \mathrm{C}$

$450^{\circ} \mathrm{C} *$

$300^{\circ} \mathrm{C}$

$250^{\circ} \mathrm{C} *$

$14 \times 10^{-6} \mathrm{C}$

$20 \mathrm{~kg} / \mathrm{mm}^{2}$

$30 \mathrm{~kg} / \mathrm{mm}^{2}$

$850^{\circ} \mathrm{C}$

* Although $\mathrm{T}_{\boldsymbol{B} f}$ and $\mathrm{T}_{\boldsymbol{M} f}$ were measured as $400^{\circ} \mathrm{C}$ and $200^{\circ} \mathrm{C}$ respectively, they were corrected as listed above for computation. 
応力の釣合から

$$
\frac{r}{R} \frac{d \sigma_{r}}{d r}=2 d \tau
$$

以上より

$$
\begin{aligned}
& d \sigma_{r}=2 d_{\tau} \cdot J_{1} \cdot\left[-\frac{A 1}{2} \log (r / R)^{2} / n^{2}\right. \\
& \left.\quad+\frac{A 2}{2}\left\{(r / R)^{2}-n^{2}\right\}+\frac{A 3}{4}\left\{(r / R)^{4}-n^{4}\right\}\right]
\end{aligned}
$$

$$
\begin{aligned}
& -2 d \tau \cdot K_{1} \cdot\left[\begin{array}{c}
A 1 \\
2
\end{array} \frac{1}{2}\left\{(r / R)^{2}-n^{2}\right\}\right. \\
& \left.+{ }_{4}^{A 2}\left\{(r / R)^{4}-n^{4}\right\}+\frac{A 3}{6}\left\{(r / R)^{6}-\cdot n^{6}\right\}\right] \\
& \left.\begin{array}{l}
d \sigma_{t}=d \sigma_{r}+2 d \tau \\
d \sigma_{z}=\frac{1}{2}\left(d \sigma_{r}+d \sigma_{t}\right)
\end{array}\right\}
\end{aligned}
$$$$
\text { ここで } J_{1}, K_{1} \text { はマルテンサイト組織に対しては (4) }
$$$$
\text { 式の } J, K \text { に等しく, ベイナイト組織に対しては(4)式 }
$$
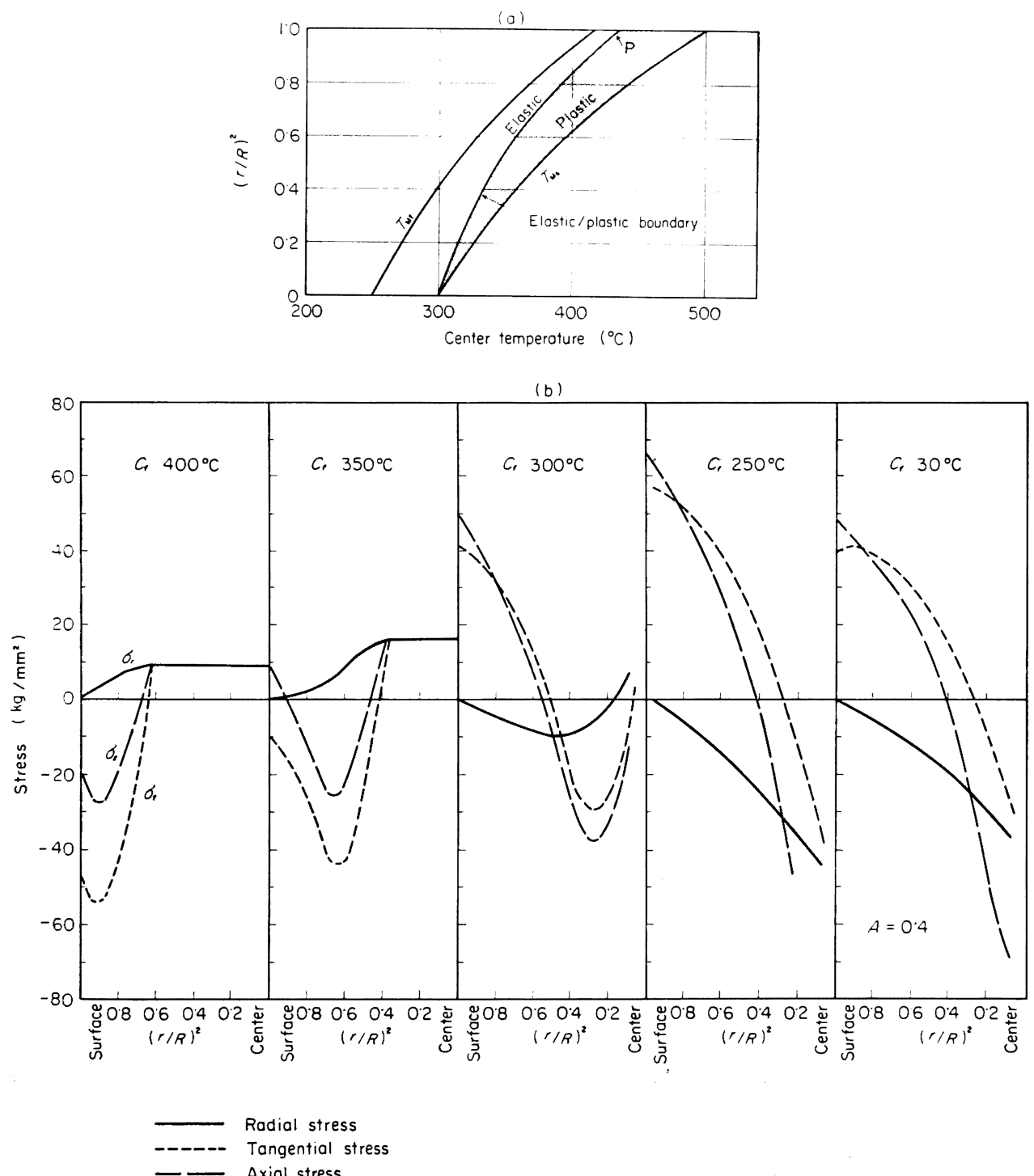

Fig. 6. Changes in distribution of states during quenching from $850^{\circ} \mathrm{C}$ (a) change in the elastic plastic boundary; and (b) stress distributions, each distribution presenting when the center temperature $C_{f}$ has become as designated. The quenched structure is fully martensitic and data for computation are given in Table 1, with $A=0 \cdot 4$. 
の $(1-J),-K$ に等しい.

$$
\begin{aligned}
& A \mathrm{l}=-2\left(T_{0}-T_{f}\right) /\left(T_{s}-T_{f}\right)^{2} \\
& A 2=2 A\left(2 T_{0}-T_{f}\right) /\left(T_{s}-T_{f}\right)^{2} \\
& A 3=-2 A^{2} T_{0} /\left(T_{s}-T_{f}\right)^{2}
\end{aligned}
$$

\section{$4 \cdot 2$ 弾性体に生ずる応力}

$$
\begin{gathered}
d \sigma_{r}=\frac{m E}{m-1}\left\{-\frac{1}{(r / R)^{2}} \int_{n}^{r / R} d \varepsilon \cdot(r / R) d(r / R)\right. \\
\frac{(r / R)^{2}-n^{2}}{(r / R)^{2}\left(B^{2}-n^{2}\right)} \int_{n}^{B} d \varepsilon \cdot(r / R) d(r / R) \\
d \sigma_{t}=\frac{m E}{m-1}\left\{\frac{1}{(r / R)^{2}} \int_{n}^{r / R} d \varepsilon \cdot(r / R) d(r / R)\right. \\
\left.+\frac{(r / R)^{2}+n^{2}}{(r / R)^{2}\left(B^{2}-n^{2}\right)} \int_{n}^{B} d \varepsilon(r / R) d(r / R)-d \varepsilon\right\} \\
d \sigma_{z}=\frac{m E}{m-1}\left\{\frac{2}{B^{2}-n^{2}} \int_{n}^{B} d \varepsilon \cdot(r / R) d(r / R)-d \varepsilon\right\}
\end{gathered}
$$

\section{3 塑性体に生ずる静水压からの応力}

塑性域

$$
d \sigma_{r}=d \sigma_{t}=d \sigma_{z}=d P
$$

弾性域

$$
\begin{aligned}
& d \sigma_{r}=\frac{n^{2}}{n^{2}-B^{2}}\left(1-\frac{B^{2}}{(r / R)^{2}}\right) d P \\
& d \sigma_{t}=\frac{n^{2}}{n^{2}-B^{2}}\left(1+\frac{B^{2}}{(r / R)^{2}}\right) d P \\
& d \sigma_{z}=\frac{n^{2}}{n^{2}-B^{2}} d P
\end{aligned}
$$

\section{5. 計 算 結 果}

以上述べたような焼入応力発生の概念と計算方法にも
とづいて求めた焼入中の応力分布は次のようであつた。 計算に必要なデータは Table 1 の值を標準として用い た。

\section{$5 \cdot 1$ 完全焼入}

マルテンサイト一相に焙入れる場合の焼入中の弾塑性 の状態と過渡的応力分布を Fig. 6 に示す. Fig. 6 は焼 入中の温度分布を示す係数 $A$ が $0: 4$ の場合で $100 \mathrm{~mm}$ 径の丸棒を油焼入れした場合に相当する．焼入れてから 中心が $500^{\circ} \mathrm{C}$ をで低下したとき表面は $300^{\circ} \mathrm{C}\left(T_{M s}\right)$ に 達し，マルテンサイト変態を開始するが, 表面が弾性化 するのは Fig. 6(a) に示されるように，P点に達して からであり，このときの中心温度は $433^{\circ} \mathrm{C}$ で，表面温 度は $260^{\circ} \mathrm{C}$ である. Fig. 6(b) は内部応力の変化を示 すが，結果の表示は縦軸に応力，横軸に $(r / R)^{2}$ をとつ て行ない，それぞれの図の右端が中心，左端が表面であ る. また，図中の $C_{f}$ は計算終了温度の意味で中心が $C_{f}$ の温度まで低下したときの過渡的応力分布を示す. 中心

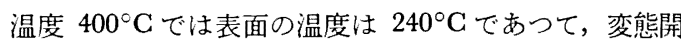
始位置は $(r / R)^{2}=0.64$ 変態終了位置は $(r / R)^{2}=0.94$ である.このときの応力分布は変態開始位置より内部は オーステナイト状態で三方向の各応力とも一様な引張り となつており, 変態域では表面側ほど圧維応力となる. 表面側の変態終了域では内部の变態膨張により応力は引 張方向に移りはじめている．温度が低下するに伴い，応 力分布は図のように変化し最終的には表面に引張応力, 内部に圧縮応力となる. 表面の引張応力が最大となるの は中心の変態が完了する直前であつて，以後熱応力だけ

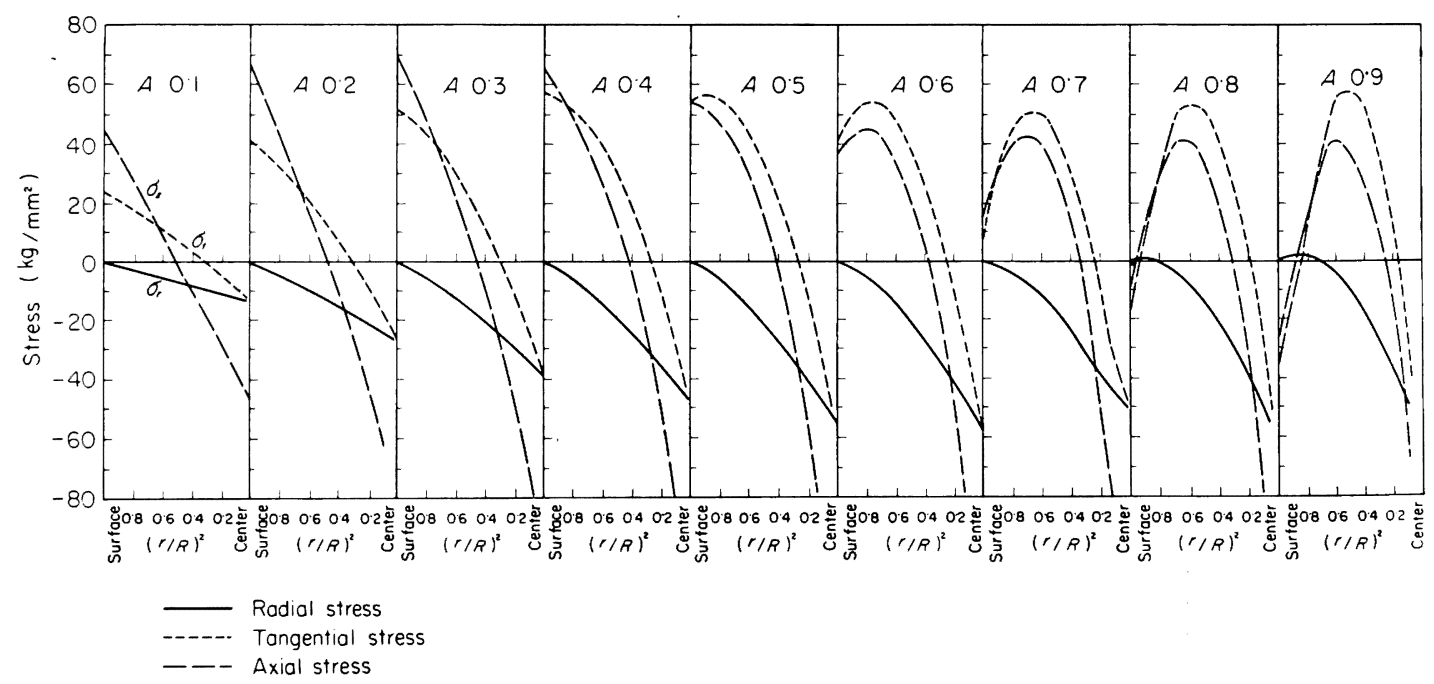

Fig. 7. Stress distributions as a function of $A$, the temperature gradient coefficient, for a case of complete quench. Center temperature $=250^{\circ} \mathrm{C}$. Data for computation are given in Table 1 . 
Table 2. Thermal stresses induced in a steel as the temperature at center is lowered from $250^{\circ} \mathrm{C}$ to room temperature.

Data for computation are given in Table 1.

\begin{tabular}{|c|c|c|c|c|c|c|c|}
\hline \multirow{3}{*}{$\begin{array}{l}\text { Temperature } \\
\text { gradient } \\
\text { coefficient, A }\end{array}$} & \multirow{3}{*}{ Direction* } & \multicolumn{6}{|c|}{ Position, $(r / R)^{2}$} \\
\hline & & $1 \cdot 0$ & $0 \cdot 8$ & $0 \cdot 6$ & $0 \cdot 4$ & $0 \cdot 2$ & $0 \cdot 0$ \\
\hline & & \multicolumn{6}{|c|}{ Stress $\left(\mathrm{kg} / \mathrm{mm}^{2}\right)$} \\
\hline $0 \cdot 1$ & $\begin{array}{l}\mathrm{T} \\
\mathrm{Z}\end{array}$ & $\begin{array}{l}-4 \cdot 8 \\
-4 \cdot 8\end{array}$ & $\begin{array}{l}-3 \cdot 4 \\
-2 \cdot 9\end{array}$ & $\begin{array}{l}-1 \cdot 9 \\
-1 \cdot 0\end{array}$ & $\begin{array}{r}-0.5 \\
1.0\end{array}$ & $\begin{array}{l}1 \cdot 0 \\
2 \cdot 9\end{array}$ & $\begin{array}{l}2 \cdot 4 \\
4 \cdot 8\end{array}$ \\
\hline $0 \cdot 2$ & $\begin{array}{l}\mathrm{T} \\
\mathrm{Z}\end{array}$ & $\begin{array}{l}-9 \cdot 7 \\
-9 \cdot 7\end{array}$ & $\begin{array}{l}-6 \cdot 8 \\
-5 \cdot 8\end{array}$ & $\begin{array}{l}-3 \cdot 9 \\
-1 \cdot 9\end{array}$ & $\begin{array}{r}-1 \cdot 0 \\
1 \cdot 9\end{array}$ & $\begin{array}{l}1 \cdot 9 \\
5 \cdot 8\end{array}$ & $\begin{array}{l}4 \cdot 8 \\
9 \cdot 7\end{array}$ \\
\hline $0 \cdot 3$ & $\begin{array}{l}T \\
Z\end{array}$ & $\begin{array}{l}-14 \cdot 4 \\
-14 \cdot 4\end{array}$ & $\begin{array}{r}-10.1 \\
-8.7\end{array}$ & $\begin{array}{l}-5 \cdot 8 \\
-2 \cdot 9\end{array}$ & $\begin{array}{r}-1 \cdot 4 \\
2 \cdot 9\end{array}$ & $\begin{array}{l}2 \cdot 9 \\
8 \cdot 7\end{array}$ & $\begin{array}{r}7 \cdot 2 \\
14 \cdot 5\end{array}$ \\
\hline 0.4 & $\begin{array}{l}\mathrm{T} \\
\mathrm{Z}\end{array}$ & $\begin{array}{l}-19 \cdot 3 \\
-19.3\end{array}$ & $\begin{array}{l}-13 \cdot 5 \\
-11.5\end{array}$ & $\begin{array}{l}-7 \cdot 7 \\
-3 \cdot 9\end{array}$ & $\begin{array}{r}-1 \cdot 9 \\
3 \cdot 7\end{array}$ & $\begin{array}{r}3 \cdot 9 \\
11 \cdot 5\end{array}$ & $\begin{array}{r}9 \cdot 7 \\
19 \cdot 3\end{array}$ \\
\hline 0.5 & $\begin{array}{l}\mathrm{T} \\
Z\end{array}$ & $\begin{array}{l}-24 \cdot 1 \\
-24 \cdot 1\end{array}$ & $\begin{array}{l}-16 \cdot 9 \\
-14 \cdot 4\end{array}$ & $\begin{array}{l}-9 \cdot 7 \\
-4 \cdot 8\end{array}$ & $\begin{array}{r}-2 \cdot 4 \\
4 \cdot 8\end{array}$ & $\begin{array}{r}4 \cdot 8 \\
14 \cdot 4\end{array}$ & $\begin{array}{l}12 \cdot 0 \\
24 \cdot 0\end{array}$ \\
\hline $0 \cdot 6$ & $\begin{array}{l}\mathrm{T} \\
\mathrm{Z}\end{array}$ & $\begin{array}{l}-28 \cdot 9 \\
-28 \cdot 9\end{array}$ & $\begin{array}{l}-20 \cdot 2 \\
-17 \cdot 3\end{array}$ & $\begin{array}{r}-11 \cdot 5 \\
-5 \cdot 8\end{array}$ & $\begin{array}{r}-2 \cdot 9 \\
5 \cdot 8\end{array}$ & $\begin{array}{r}5 \cdot 8 \\
17 \cdot 3\end{array}$ & $\begin{array}{l}14 \cdot 4 \\
28 \cdot 8\end{array}$ \\
\hline 0.7 & $\begin{array}{l}\mathrm{T} \\
\mathrm{Z}\end{array}$ & $\begin{array}{l}-33 \cdot 8 \\
-33 \cdot 8\end{array}$ & $\begin{array}{l}-23 \cdot 6 \\
-20 \cdot 2\end{array}$ & $\begin{array}{r}-13 \cdot 5 \\
-6 \cdot 8\end{array}$ & $\begin{array}{r}-3 \cdot 4 \\
6 \cdot 8\end{array}$ & $\begin{array}{r}6 \cdot 8 \\
20 \cdot 2\end{array}$ & $\begin{array}{l}16 \cdot 9 \\
33 \cdot 7\end{array}$ \\
\hline $0 \cdot 8$ & $\begin{array}{l}\mathrm{T} \\
\mathrm{Z}\end{array}$ & $\begin{array}{l}-38 \cdot 6 \\
-38 \cdot 6\end{array}$ & $\begin{array}{l}-27 \cdot 0 \\
-23 \cdot 1\end{array}$ & $\begin{array}{r}-15 \cdot 4 \\
-7 \cdot 7\end{array}$ & $\begin{array}{r}-3 \cdot 9 \\
7 \cdot 7\end{array}$ & $\begin{array}{r}7 \cdot 7 \\
23 \cdot 1\end{array}$ & $\begin{array}{l}19 \cdot 3 \\
38 \cdot 5\end{array}$ \\
\hline $0 \cdot 9$ & $\begin{array}{l}\mathrm{T} \\
\mathrm{Z}\end{array}$ & $\begin{array}{l}-43 \cdot 4 \\
-43 \cdot 4\end{array}$ & $\begin{array}{l}-30 \cdot 4 \\
-26 \cdot 0\end{array}$ & $\begin{array}{r}-17 \cdot 3 \\
-8 \cdot 7\end{array}$ & $\begin{array}{r}-4 \cdot 3 \\
8 \cdot 7\end{array}$ & $\begin{array}{r}8 \cdot 7 \\
26 \cdot 0\end{array}$ & $\begin{array}{l}21 \cdot 7 \\
43 \cdot 3\end{array}$ \\
\hline
\end{tabular}

* $\mathrm{T}:$ Tangential; $\mathrm{Z}:$ axial

が発生するため室温に澾したもきには多少減少した状態 になる。

表面の引張応力が最大になるのは中心の変態が完了す る直前であるので，中心が $250^{\circ} \mathrm{C}$ に達したときの応力 分布を $A=0.1 \sim 0.9$ の場合について Fig. 7 に示寸.

$A$ の值が大きくなることは同じ焼入方法の場合は鋼の直 径が大きくなることを意味し, 鋼の直径が同じならば冷 却の方法が急激になることを意味するが $A$ の值が大きく なると接線方向, 軸方向ともに表面の応力は引張側に大 となり, $A=0.4 \sim 0.6$ で最大に達し以後低下する. ま た応力のピークは $A=0.5$ 以上になると表面より内部 に移る. 室温に打ける応力分布, 寸なわち焼入残留応力 は Fig. 7 の值に Table 2 の熱応力が加わるため $A=$ 0.65 以上で表面の応力は圧縮となる.

変態に関する物性値の影響を調べた結果を Fig. 8 に 示す. 標準として Table 1 のデータによる結果を(a) に示し, 変態昰, マルテンサイトの望断弾性限むよび変 態点を独立に変化して計算した結果を（b)〜 ( h ) に示 す. Fig. 8 は $A=0.4$ の場合で中心の変態が完了した
時点での応力分布である. ( b ), ( a ) おざ ( c ) 図は変 態歪を $0.3,0.5$ および 0.70 。にした場合で, 変態歪が 大なる活ど表面の応力は引張側:大となり, 接線方向応 力が粙方向応力よりも大となることを示している.(d)， (a)および (e)図はマルテンサイトの剪断弾性限を20, 30 および $40 \mathrm{~kg} / \mathrm{mm}^{2}$ にした場合で, 剪断弾性限が大 となるほど表面の応力は小となる。この理由は変態歪の うち望性となる割合が少くなることによる．（f)，（a） および $(\mathrm{g})$ 図は $T_{M s}$ と $T_{M f}$ の温度差を一定にして $T_{M s}$ を 400,300 および $200^{\circ} \mathrm{C}$ とした場合である.この場 合は同じ $A$ でも変態点が低い上, 変態点こおける温度勾 配が小さくなるので， $A$ を小さくすることと同じ結果に なる.（f)，（g)図はそれでれ Fig. 7 の $A=0.5 ， 0.3$ とほとえど等しい. ( $\mathrm{h}$ )図は $T_{M s}$ と $T_{M f}$ の温度差を $100^{\circ} \mathrm{C}$ とした場合で熱歪に対する梁態歪の割合が小さく なり応力として小さくなる.

\section{$5 \cdot 2$ 不完全焼入}

ベイナイトとマルテンサイトの二相に焼入れたよきの 応力分布の変化を Fig. 9 に示声. Fig. 9 の応力は焼 


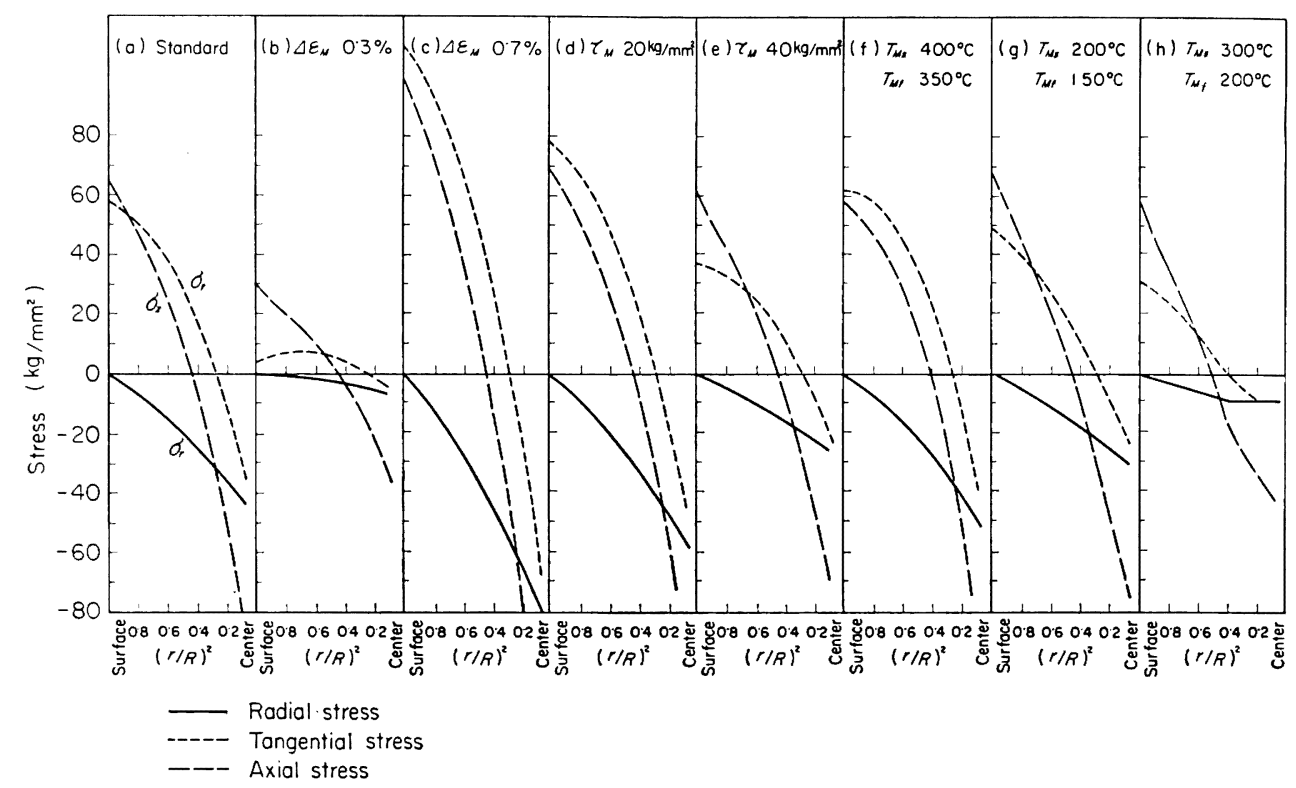

(a) : Standard as shown in Table 1;

(b) and (c) : Transformation strain is varied, $0.3 \%$ vs $0.7 \%$;

(d) and (e): Elastic shearing strength is varied, $20 \mathrm{~kg} / \mathrm{mm}^{2}$ vs $40 \mathrm{~kg} / \mathrm{mm}^{2}$;

(f) and ( g ) : $T_{\mathrm{Ms}}$ and $T_{\mathrm{Mf}}$ are varied, while keeping the difference constant, $400^{\circ} \mathrm{C}$ and $350^{\circ} \mathrm{C}$ vs $200^{\circ} \mathrm{C}$ and $150^{\circ} \mathrm{C}$;

(h): The difference between $T_{\mathrm{Ms}}$ and $T_{\mathrm{Mf}}$ is varied, $T_{\mathrm{Ms}}=300^{\circ} \mathrm{C}$ and $T_{\mathrm{Mf}}=200^{\circ} \mathrm{C}$.

Fig. 8. Influence of physical properties of steel on the stress distribution as the transformation at the center is completed.

入組織の比が右端に示したような場合で $A=0.5$ であ る. 完全烧入と異ふつて応力分布が複雑になつている が，マルテンサイト量が多いときは変態終了直前に表面 近くの引張応力が最大になることは同じである. Table 1 のデータを用いて，多くの焼入組織に対し，中心の変 態が完了する時点での応力分有を Fig. 10 に示寸. 不完 全烍入の場合は全体上してのベイナイトとマルテンサイ 卜の比, 表面と中心の組織の学去どが影響するため応力 分布は単純では恣いが傾向を整理与れ計次のとおりであ み.（1）全体としての焼入組織にベイナイトのしめる割 合が多くなる之表面に圧縮, 内部に引張応力となる.こ

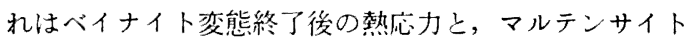
変態の影響が小さくなるためである.（2)表面と内部の 組織の差が大きくなると表面は圧縮応力となる. (3) $A$ の值が 0.5 以上になると表面よりやや内部に引張応力の ピークが存在すうようになり，Aの増大とともに内部に 移つてゆく（4)接線方向と軸方向応力には大きな差は ない。

\section{6. 考察}

Fig. 7 と Fig. 10 は鋼の中心温度が变態終了温度
$\left(T_{M f}\right)$ まで低下したときの過渡的応力分布であるので, 鋼全体が室温まで泠却したときの応力分布，すなわち， 烧入残留応力は Table 2 に示寸熱応力をおのおのの図 の応力に加兑るここによつて求められる.焼入中の銅の 断面における温度公配を示寸倸数 $A$ と, 表面と中心の焼 入組織の差には，何らかの閔倸があるはずなのでたと

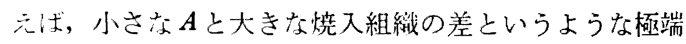
な組み合わせは実際の烧入では存在しないことを念頭に おく必要がある。

計算に用いた Table 1 の值は SCM4 の実測値を基 本としたものである。計算結果の検討は今までに発表さ 记た焼入残留応力の実測值 ${ }^{9110)}$ と比較することによつて 行なつた. $H$. BüLER らは直径 $100 \mathrm{~mm}$ までの鋼につい て焼入残留応力を乐統的整理しているので9)，ここで は主として彼らの報告と比較を行なう・油焼入において は, 鋼全体か $450^{\circ} \mathrm{C}$ 以下で変態する組織だけに焼入れら れた場合, 焼入残留応力は表面で引張応力, 中心で圧縮 応力となるが, 焼入組織中に高温变態組織が多くなるほ ぞ，また，鋼の直径が大きくなるほど表面応力は圧縮側 に移つて行き,また, 水焼入の場合は, 高温変態組織が多 くなるほよ゙，また試片の直径が大きくなるほど表面応力 


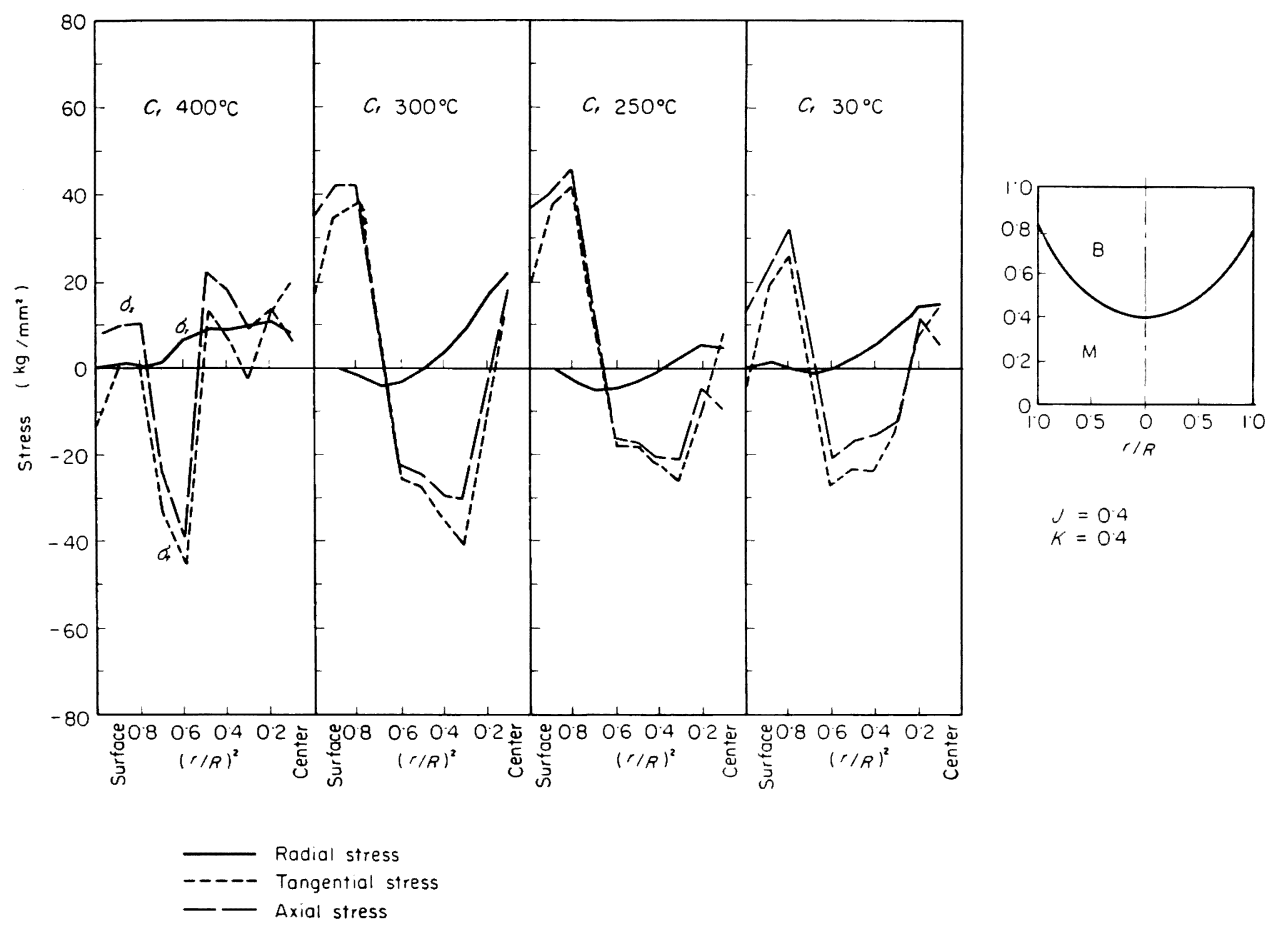

Fig. 9. Transient stress distributions in the case of incomplete quenching from $850^{\circ} \mathrm{C}$ as the center temperature $C_{f}$ becomes as designated. Data for computation are given in Table 1 with $A=0 \cdot 5, J=0 \cdot 4$, and $K=0 \cdot 4$.

は圧繀になる傾向のあることが知られている．鋼の直径 を増加することは本計算の $A$ を増加することと同じであ り, Fig. 7 と Fig. 10 にみられる傾向は上述の実測值 にみられる傾向と一致している. Fig. 10 にみられるせ まい引張応力のピークは，実測ではほとんど報告されて いない. しかし，この引張応力のピークについては後節 で述べる焼割れ試験に扔いて定性的ではあるが，ての存 在が証明された、実測では鋭い引張応力の存在がみとめ られないのは, 残留応力を速続的に測定することがむず かしく，ある厚さごとの平均值として求めることによる と考えられる.

マルテンサイト変態開始温度が応力分布に与える影響 として $H$. BüLER は直径 $50 \mathrm{~mm}$ の $\mathrm{Fe}-\mathrm{Ni}$ 合金を水水 焼入した場合について報告9している． $T_{M s}$ を $450^{\circ} \mathrm{C} か$ ら $250^{\circ} \mathrm{C}$ まで低下すると表面の残留応力は压縮から引 張に変わつてくる. すでに Fig. 8 の説明で述べたよう に， $T_{M s}$ を低下することは $A$ の值を低下することと同 じである. Fig. 7 にみられるように $T_{M s}$ のかわりに $A$ を変化させた計算結果は同様の傾向を示している.

\section{7. 内部応力計算結果の熱処理への応用}

すでに述べたように焼制れの原因は焼入鋼の破壊強さ を越えるような内部応力の発生とこの応力を塑性変形に よつて吸収しえない鋼の低い塑性能である.焼入れた鋼 の塑性能は主として炭素含有量によつてきまり, 炭素量 の増加と共に塑性能は低下し，0.47\%以上の炭素を分兑 ことによつて焼入れた鋼の塑性能はゼロとなる.大型鍛 鋼品の傹入れに水筧入れを採用与る可能性を調べるため Fig. 11 亿示与 3 コの中炭素クロム・モリブデン鋼を850 ${ }^{\circ} \mathrm{C}$ より水焼入れした。 これらの品物は寸法上化学成分 より，わずかにベイナイトを含む不完全焼入組織ふらフ エライトを含むべイナイトの不完全焼入組織充でに焼入 れられることを予想したもので，内部応力と鋼の塑性能 から焼割れに対して安全であると子想した，焼入れた結 果，焼制れを尘じたのは直径 $400 \mathrm{~mm}$ の部分だけであつ

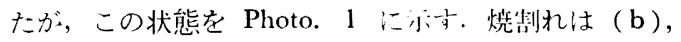
(c)にみられるように表面よりわずか内部に発生してお り, さらに内部の灰色の部分は中心部における引張残留 応力により 2 週間ほ上゙の放置中に制れたものである。外 
鉄 と 鋼 第 57 年 (1971) 第14号
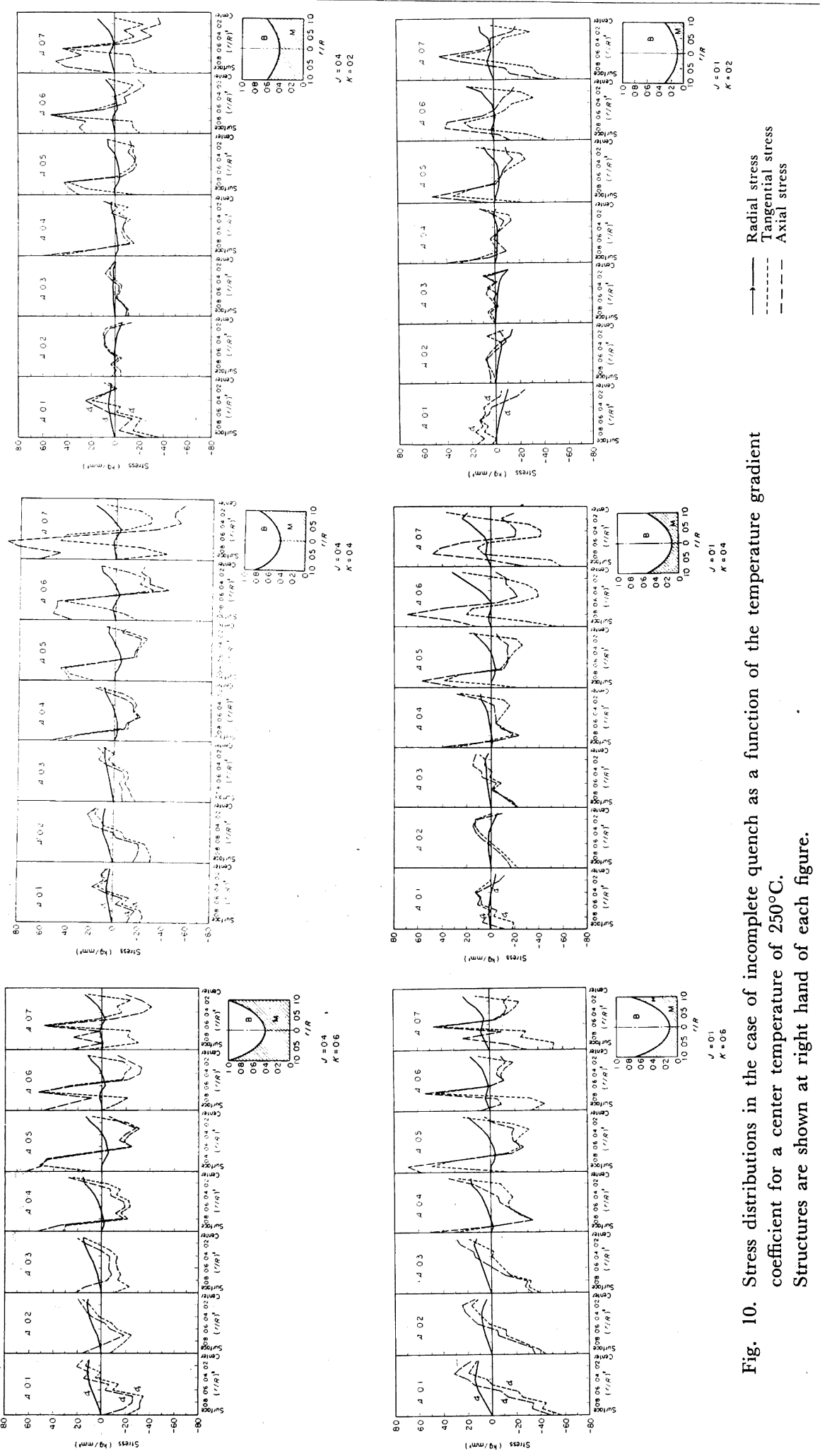


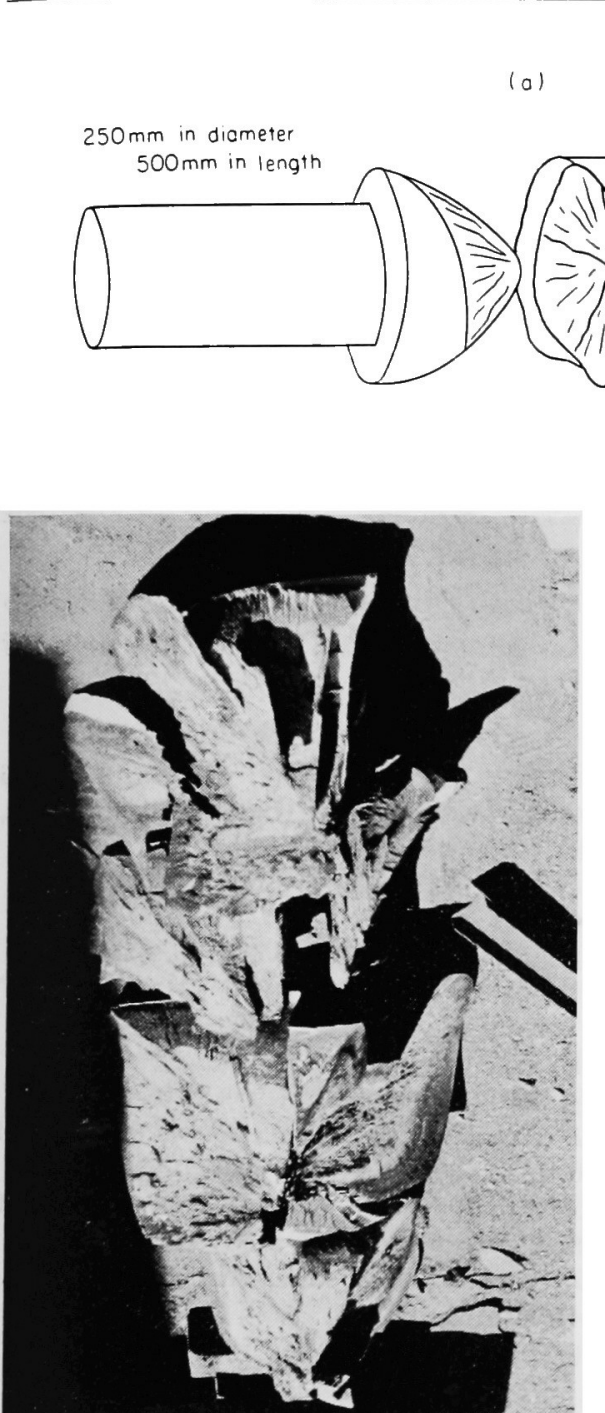

(b)

(a) Sketch of the fracture.

(b) A portion that was broken into four blocks; and

(c) A close-up view, where the dar'k areas are the primary quench-cracks.

Photo. 1. Fracture of a medium carbon $\mathrm{Cr}-\mathrm{Mo}$ steel. The steel was water-quenched from $850^{\circ} \mathrm{C}$, No quench-crack was observed with naked eye, but after laying it outdoors about two weeks, severe cracks grew in it.

周の白い部分は最後えで破壊せずハンマーで破壊したと きの破面である.この部分の焼入かたさは中心部で $\mathrm{HB}$ 260 であり多量のフェライトを含えでいたことが示され ている．この焼割試験から定性的ではあるが次のこ上が わかつた。

（a）表面放らずか内部に引后応力のピークが存在 することは計算の結果を裹付けている.

(b) 計算上引張応力のピークが存在し，たま沉危険 と思われる値となることがあるが，鋼の塑性能が十分で
ない場合はょはり境制れは発生する。

以上のよう衣考虑に立つて烍割れに対する安全域を確 立し，著者らは $40 \mathrm{t}$ を越える鋼材を今までの油烍入に かえて水焼入を行ない鋼材の引|張強さの值を $15 \sim 20 \mathrm{~kg} /$ $\mathrm{mm}^{2}$ 程度增加せしめることができた

\section{8. 結言}

大型鋼材の強鞄化々残留応力利用による疲労強さ向上 を計るための基礎として焼 入応力を計算によつて求め 


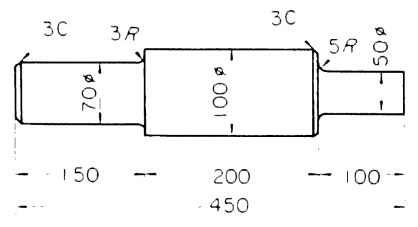

$0+1 \mathrm{C}, 033 \mathrm{~S}, 0.84 \mathrm{Mn}, 101 \mathrm{Cr}, 0.20 \mathrm{Mo}$
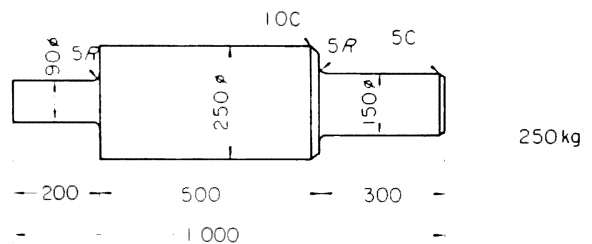

$043 \mathrm{C}, 025 \mathrm{Si}, 0.81 \mathrm{Mn}, 109 \mathrm{Cr}, 020 \mathrm{Mo}$

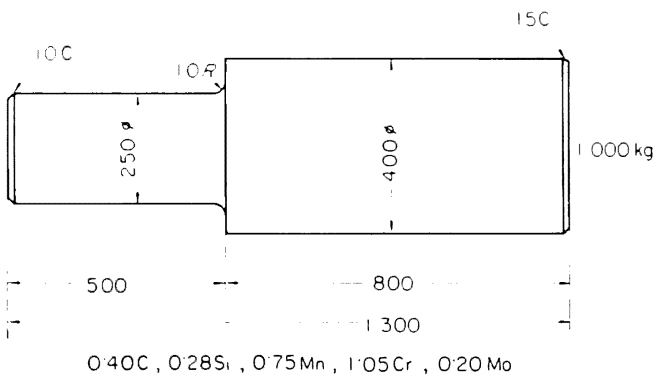

Fig. 11. Profiles and chemical compositions of test pieces for quench-cracking test.

た。

本計算方法の要点は次のとおりである.

1）往来末解決であつた烍入中の弾塑性の分離を最大 剪断応力説を用いて解決した

2）焼入応力の発生を泠却の㭙間上してではなく，温
度分们の変化としてとらえた。䤱の大きさは焼入中の温 度公配としてとら元，敛の大きさを無次元化した。

計算結果は次のようであーた。

3）稘入の過渡状態において表面側に引張応力の最大 が生ずるのは中心部の变態が完了する直前である.

4) 完全焼入に沶いて高い引狠応力が現れるのは $A=$ $0.4 \sim 0.6$ の中間的急冷の場合であう.

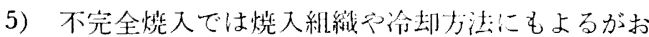
打当权表面には压縮応力が残留与る。そして表面直下に 引張応力の鋭いピークを持つことがある。

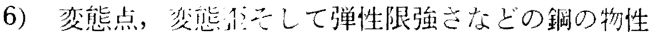
倠は㘹入応力の值に大きく影響する。

これらの計算結将は文献による残留応力の実測とくら ベてよく一致しており，嘴割りによる定性的裏付けを行 放つた。

\section{交献}

1) 利阔，雑賀，栗山：鉄と鋼，54(1968) 4, p. 416

2 ) $G$. Bandel and $H^{r}$. C. Haumer: Stahl u. Eisen, 84 (1964) 15, p. 932

3 ) Ed. Maurer: Stahl i. Eisen, 47 (1927), p. 1323 交献 4 ) より

4 ）広根：理研案跎，14 (1935) 7, p. 525., 15 (1936) 5, p. $243 ., 16$ (1937) 11, p. 1230

$5)$ 下田：日本金属学会誌，B-14 (1950) 3, p. 13

6 ) W. H. GieLt, 横堀訳: 基礎伝熱工学 (19557), p. 260, 丸善

7 ) F. Hengerer, $B$. Strässle, and P. Bremi: Stahl u. Eisen, 89 (1969) 12, p. 641

8 ) A. Nadal: Theory of Flow and Fracture of Solids, (1950), p. 211 McGraw-Hill N.l.

9 ) $H$. Bühler and $A$. Rose: Arch. Eisenhüttenw., 40(1969) 5, p. 411

10) 僟村：鉄と鋼，47（1964）7, p. 936 